\title{
Organizational Commitment in the Cross-functional Relation: Case of the Moroccan Hospital Supply Chain
}

\author{
M. Bouachouch and H. Lamrabet
}

\section{ABSTRACT}

In recent years, the environment of health systems has been changing particularly with the rapid progression of the COVID-19 pandemic. Indeed, since February 2020, the COVID-19 has constituted a major challenge for the health system, in general, and an organizational challenge for all hospitals, in particular, where the quality of inter-functional relationships plays an essential role. Thus, the internal services of the hospital require critical interactions in order to anticipate a significant influx of patients. In this perspective, this research aims to conceptualize the hospital as a Hospital Supply Chain (HSC) and explore the causal relationship between organizational commitment and cross-functional relationships in the HSC context. In doing so, the analysis of the literature makes it possible to deduce a series of propositions. In this sense, an exploratory qualitative study, based on semi-structured interviews, makes it possible to compare our theoretical framework with the empirical framework.

Keywords: Cross-functional Relationships, Moroccan Hospital System, Organizational Commitment, Supply Chain

Published Online: January 24, 2022

ISSN: 2736-5522

DOI: 10.24018 / ejsocial.2022.2.1.52

M. Bouachouch*

National School of Commerce and Management, Sidi Mohamed Ben Abdellah University-Fes, Kingdom of Morocco.

(e-mail: bouachouch.scm ${ }^{@}$ gmail.com). H. Lamrabet

National School of Commerce and Management, Sidi Mohamed Ben Abdellah University-Fes, Kingdom of Morocco.

(e-mail: hicham.lamrabet@usmba.ac.ma)

*Corresponding Author

\section{INTRODUCTION}

The health systems environment has undergone multiple changes in recent years (Kosremelli, 2011): the growth in health spending, the aging of the population, the integration of technologies, the growth of infectious diseases (Ebola virus disease, Severe Acute Respiratory Syndrome (SARS), Corona Virus Disease (COVID-19)... In such an environment, hospitals must reinvent themselves and develop their practices, in this case, their management systems.

Since February 2020, the rapid progression of the COVID-19 pandemic has been an organizational challenge for all hospitals where the hospital's internal services require critical interactions in order to deal with the large number of hospitalized patients (Garnier et al. 2020). Thus, operating models in silos do not meet the challenges of the hospital. The latter must call into question its compartmentalized management while giving a great place to innovation by the establishment of new logistics approaches and practices making it possible to reduce the increasing fragmentation from which hospitals are suffering (Boelen, 2000). From this perspective, conceptualizing the hospital as a Hospital Supply Chain (HSC) is an innovative approach that reduces this fragmentation and anticipates large influxes of patients.

The HSC can be defined as "a set of intra-hospital entities (administration, logistics services, medical units and medico-technical units) and inter-hospital (suppliers, laboratories, wholesalers, patients) directly involved in the physical flow, informational and financial since the first suppliers to patients and willing to coordinate for a common goal: patient satisfaction" (Bouachouch et Ouazzani, 2015). The success of the HCS clearly depends on the relationships between the internal departments of the hospital. In other words, inter-functional relations (IFR).

Our research conceptualized the hospital as an HSC in order to reduce the fragmentation suffered by hospitals and explore the causal relationship between organizational commitment and inter-functional relationships in the context of HCS. Thus, our research question is structured as follows: "What is the impact of Commitment on inter-functional relationships in the context of the Moroccan university hospital center SC?" To answer it, we will first present the theoretical framework of the research, we will then specify the methodology adopted, and we will finally lead to the results and discussions. 
European Journal of Humanities and Social Sciences www.ej-social.org

\section{CONCEPTUAL FRAMEWORK AND RESEARCH PROPOSALS}

\section{A. IFR in the Context of the HSC}

\section{The HSC}

Over the past 20 years, there is abundant literature that examines the SC approach in the industrial sector, but there is limited academic literature that addresses the challenges of health care (McKone-Sweet et al., 2005). Nonetheless, with these small literature examining hospital SC, there is general agreement that HSC and their management are complex. The following table lists the definitions found in the literature:

\begin{tabular}{|c|c|}
\hline Authors & Definitions of SCH \\
\hline Taher (2006) & $\begin{array}{l}\text { HSC "aims to coordinate the partners, from the first suppliers (manufacturers or transporters) to the last } \\
\text { distributors (care services / patients), whose interdependent activities allow the development of a product or } \\
\text { service and its availability to the end customer." }\end{array}$ \\
\hline $\begin{array}{l}\text { Di Martinelly } \\
\text { (2008) }\end{array}$ & $\begin{array}{l}\text { HSC "as the activities of design, planning, implementation and control of coordination mechanisms between } \\
\text { patient's flows and diagnostic and therapeutic activities in health service organizations." }\end{array}$ \\
\hline $\begin{array}{l}\text { Andre and } \\
\text { Fenis (2007) }\end{array}$ & $\begin{array}{l}\text { HSC "An open set crossed by human, material, information and financial flows, composed of various } \\
\text { autonomous entities: suppliers, hospital services (emergency, operating theater, etc.), logistics providers, } \\
\text { medical providers, etc. these entities use consumable resources in limited number (equipment, capital, etc.) and } \\
\text { coordinate their action through an integrated logistical process in order to primarily improve their collective } \\
\text { performance (patient satisfaction, optimization of the functioning of the hospital system) but also ultimately } \\
\text { their individual performance (maximization of value created by an entity)." }\end{array}$ \\
\hline $\begin{array}{l}\text { Acharyulu } \\
(2012)\end{array}$ & $\begin{array}{l}\text { HSC "is the network of outside organizations involved through upstream and downstream linking of different } \\
\text { processes, procedures and activities inside the organization that add value in the form of services to achieve a } \\
\text { high quality healthcare to the ultimate patient." }\end{array}$ \\
\hline $\begin{array}{l}\text { Ibn El Farouk } \\
\text { and al, (2012) }\end{array}$ & $\begin{array}{l}\text { HSC is "a set of processes that exchange physical, information and financial flows in the but to ensure all the } \\
\text { conditions necessary to offer a better quality service to the patient." }\end{array}$ \\
\hline $\begin{array}{l}\text { Bouachouch } \\
\text { and }\end{array}$ & $\begin{array}{l}\text { The HSC can be defined as "a set of intra-hospital entities (administration, logistics services, medical units and } \\
\text { medico-technical units) and inter-hospital (suppliers, laboratories, wholesalers, patients) directly involved in the }\end{array}$ \\
\hline $\begin{array}{l}\text { Ouazzani, } \\
\text { 2015). }\end{array}$ & $\begin{array}{l}\text { physical flow, informational and financial since the first suppliers to patients and willing to coordinate for a } \\
\text { common goal : patient satisfaction." }\end{array}$ \\
\hline
\end{tabular}

Based on the table, we can see that the success of the HSC clearly depends on the relational quality between the actors of the HSC (coordination). Relational quality can be seen as the degree of suitability of a relationship to meet the client's needs associated with that relationship (Hennig-Thurau \& Klee, 1997).

\section{Inter-functional relations: coordination-integration-cooperation-collaboration}

A review of the literature reveals that relational forms (integration, cooperation, collaboration, coordination) are often used interchangeably (Moharana et al., 2012). On the other hand, according to Pinto et al. (1993), these terms can have a common denominator. Indeed, although each of the terms has distinct names, they refer to a similar idea and overlap, as evidenced by the commonalities in their definitions. The lowest common denominator that integrates the four concepts is a common behavior towards a goal of common interest.

TABLE II: ASSOCIATED COORDINATION TERMS

\begin{tabular}{cc}
\hline \hline Relational form & Authors \\
\hline Coordination & Argote 1982; Van De Ven, Delbecq and Koenig, 1976; Day et Kelein, (1987); Hodge et al., (1996); Naver \\
and Slater (1990), Olson, Walker and Rukert (1995) & $\begin{array}{r}\text { and } \\
\text { Integration }\end{array}$ \\
Cooperation & Schermerhorn (1975); Sherif and Sherif (1969) \\
Collaboration & Trist (1977) \\
\hline \hline
\end{tabular}

Source: Adapted from Pinto and al (1993) and Min (2001)

These relational forms can take on several dimensions in the context of SC (Mentzer et al., 2001; Balou et al., 2000) (figure):

1- Intra-organizational relationship: the relationships between the internal actors of the SC member organization. We can distinguish two relational dimensions:

- Intra-functional relationship: between the activities within the logistics function

- Inter-functional relationship: between the different functions of the internal CS

2- Inter-organizational relationship: between the different CS organizations.

The literature is known by several definitions of IFR: 
TABLE II: THE LITERATURE IS KNOWN BY SEVERAL DEFINITIONS OF IFR:

\begin{tabular}{|c|c|}
\hline Authors & The definitions of the IFR \\
\hline $\begin{array}{l}\text { Narver and Slater } \\
(1990)\end{array}$ & The integration and collaboration of various functional areas within an organization \\
\hline Hodge et al. (1996) & As coordination among various tasks to ensure overall goals \\
\hline Min (2001) & $\begin{array}{l}\text { Coordinated efforts across functions to accomplish common goals, such as creating customer value and } \\
\text { responsiven ess to market changes, under close relationships among the functions }\end{array}$ \\
\hline Eng (2005) & Coordination of supply chain activities and information flows across business functions and between firms \\
\hline Tay and Tay (2007) & Refers to the degree of cooperation between the different functions/departments within the organization \\
\hline Farzard et al. (2008) & The cooperation between the different functions or departments within the organization. \\
\hline Peng and George & $\begin{array}{l}\text { The communication and sharing of information and resources, and integration and collaboration of different } \\
\text { functional areas/departments. }\end{array}$ \\
\hline $\begin{array}{l}\text { Zhao and Cavusgil } \\
(2006)\end{array}$ & The integration of all functions in a company to meet and meet the needs, desires and demands of customers \\
\hline
\end{tabular}

One of the main issues of the IFR in the context of the SC that has aroused the interest of researchers, is the commitment of the personnel of the different functions as a key antecedent of the IFR within the Hospital Supply Chain (Min, 2001 ; Mentzer et al., 2001 ; Bouachouch \& M. Mamad, 2014).

\section{B. Organizational Commitment and IFR in the Context of the HCS}

Commitment is the degree to which individuals at all levels of the organization are engaged in pursuing the mission and working collaboratively to achieve organizational goals (Zakari et al., 2013). In the same vein, Maltzun Kohli (1996) assert that people who are committed to their organization have more the desire to follow the objectives of the organization and, thus, have the motive to seek cross-functional interactions. to find ways to achieve these goals. Thus, commitment is a key antecedent of IFR (Mentzer et al., 2001; Min, 2001).

The definition of commitment has its beginnings in sociology and psychology (Wong \& Sohal, 2002). The literature is marked by the existence of several definitions : Kanter (1968), Sheldon (1971), Hall, Schneider and Nygren (1970), Buchanan (1974), Mowday, Porter and Steers (1982), Becker (1960), Hrebiniak and Alutto, (1972), Wiener and Gechman, (1977), Wiener (1982), Marsh and Mannari, Allen and Meyer (1991)....

This diversity in definitions has led to confusion in research and management practices. Thus, it is preferable to choose a definition and a measure for organizational commitment, in order to avoid the lack of clarity in our research. This is why we choose the work of Meyer and Allen (1991): Organizational commitment is defined as "a psychological state that (a) characterizes the employee's relationship with the organization, and (b) has implications for the decision to continue or discontinue membership in the organization" (Meyer \& Allen, 1991). They proposed a three-dimensional conceptualization of commitment: affective, Continuance and normative.

Affective commitment: is an individual's emotional orientation towards the organization and a developing process. The individual works in an organization and stays within it because he wants to; he adopts the ideas and goals of the organization as his own (Meyer \& Allen, 1991). The individual feels like a part of the organization for which he works.

The attachment of the individual to a group or to an idea is an emotional act (Kanter, 1968) which can develop and become an identification of the employee with the organization (Sheldon, 1971). This author describes an individual's commitment to the organization as behavior that persists for a period of time during which the individual does not accept other possibilities. This, in a way, builds an affinity with the goals and values of the organization (Buchanan, 1974). It is an emotion that encourages the identification of the individual, who adopts the goals of the organization as their own.

Continuance Commitment: People join because the costs associated with other behavior are too high, not because they have an emotional attachment to the object of their commitment. The individual proves his loyalty to his organization because he needs it Meyer and Allen (1984). He acts like a pragmatic person who realizes that he will gain more benefits than disadvantages if he stays with the company. As a result, the employee realizes that leaving their organization is associated with costs (Meyer \& Allen, 1984).

Normative Commitment: Guest (1998) explains the employee's attachment to the organization by the notion of psychological contract, which was executed by Schein (1978) as a number of unspoken reciprocal expectations between employee and organization. Another definition has been suggested by Kotter (1973), who views the relationship between employee and organization as an implicit contract between an individual and his organization. This contract stipulates the expectations of both parties of each other (Kotter, 1973). It is a feeling of obligation that encourages the individual to continue working in his company.

It is through these three dimensions that we clarify the role and impact of commitment on the IFR. These findings lead us to propose: 
- P1. The Affective Commitment has a positive effect on the IFR in HSC context

- P2. The Continuance Commitment has a positive effect on the IFR in HSC context

- P3. The Normative Commitment has a positive effect on the IFR in HSC context



Fig. 1. Model Search

\section{ReseARCH Methodology}

\section{A. Epistemological Positioning and Reasoning Logic}

The main objective of our research is to discover reality through understanding and explaining the phenomenon of ICF. In this sense, we have adopted positivism.

The process of our research goes from general to particular. It begins with theoretical analyzes, continues with the translation of these into proposals which must be verified, in the end, in the field. So the logic of our research is part of a mortgage-deductive logic.

\section{B. Research Strategy}

First of all, our research explains a little studied phenomenon. It is an innovative and uncommon approach in management science. Thus, our research must be part of exploration in order to produce innovative results. Then, such an exploration implies a qualitative approach which seems to us more relevant because this approach is more suited to exploratory objectives. Finally, we have chosen to carry out the case study insofar as it allows us to study a specific phenomenon in depth. Our case is CHU Alpha. It is considered among the most important teaching hospitals in Morocco. It is made up of several hospitals and a General Management.

\section{The Data Collection}

Our study has two main sources of data collection. The so-called secondary data which have multiple forms: report, press review, internal documents, website, publications, database and the so-called primary data corresponding to the information obtained during the face-to-face interviews (this is of 20 semistructured interviews). These interviews are carried out using an interview guide composed of the themes of our research. 
European Journal of Humanities and Social Sciences www.ej-social.org

TABLE III: THE RESEARCH SAMPLE

\begin{tabular}{cc}
\hline \hline Interviewees & Interviewees \\
\hline Doctor & Head of service of Pneumology \\
Poctor & Hesor at the Faculty of Medicine \\
Professor at the Faculty of Medicine & Head of service of Central Radiology \\
Doctor & Professor at the Faculty of Medicine \\
Doctor & Head of service of "A" Cardiology \\
& Professor at the Faculty of Medicine \\
Nurse & Major of service of Surgical emergency \\
Nurse & Major of service of "A" Medicine \\
Nurse & Major of service of de "B" Medicine \\
Nurse & Major of service of "A" cardiology \\
Nurse & Major of service of Central Radiology \\
Nurse & Major of service of "A" surgery \\
Nurse & Responsible of the pharmacy of service Emergency surgical \\
Nurse & Medical emergency \\
Supervisor & Head of the Unit of audit of hospital activity \\
Administrator & Chief procurement service of Beta hospital \\
Administrator & Adjunct of procurement service of Beta hospital \\
Administrator & Head of Pharmacy service of the direction of alpha UH \\
Administrator & Adjunct of Pharmacy service of the direction of alpha UH \\
Pharmacist & Head of Pharmacy service of Beta hospital \\
Pharmacist & Adjunct of Pharmacy service of Beta hospital \\
Pharmacist & Unit of Coordination of Pharmacies \\
\hline \hline
\end{tabular}

\section{Data Analysis}

Our analysis of the data involves two main methods. Thematic analysis (or content analysis): aims to cut out and classify the speeches of the interviewees according to themes and sub-themes. This was done using coding. The latter consists of setting up a list of codes emerging from the literature and during the analysis and processing of data. This coding was carried out using Nvivo software. The interviews are recorded and transcribed with a view to being coded. The software (1) excludes all the elements which are not of interest for the analysis, (2) groups the other elements by themes and sub-themes and (3) builds the analysis grid which makes it possible to establish the links between data.

\section{E. Results and Discussions}

Our goal is to determine their degrees of acceptance.

\section{Main proposal: commitment}

The commitment was cited by respondents as an antecedent of the IFR. It reinforces the will to work in a spirit of coordination, collaboration, cooperation between the members of the SC. Respondents cite the importance of commitment in coordination. This conforms to several statements:

According to a doctor: "commitment allows SC actors to work in a spirit of coordination."

According to pharmacists:

- "A person's commitment depends on how much they belong to their hospital. When staff enjoys the work they do, they are motivated to coordinate."

- "actors who are committed to their hospital are more willing to work with others."

According to the administrators:

- "Commitment is the most important element among the factors discussed in coordination."

- "If I like my hospital, of course, I will give the best of myself for this hospital."

According to the nurses:

- "if the commitment is there, the will to work is strong. Not only a desire to coordinate with others but also a desire to sacrifice oneself and give more to the hospital."

- "The commitment cannot come without consideration. The hospital must recognize the efforts of the staff"

The degree of commitment by its three dimensions: affective, calculated and normative differs according to the status of the actors of the different services of the CHU alpha.

\section{Secondary proposition 1 : Affective Commitment}

The degree of emotional commitment differs depending on the status of the actors of the different services of the CHU alpha. Doctors are found to talk about the importance of emotional commitment to the career and not to the hospital. On the other hand, pharmacists, administrators and nurses say that they do not have an emotional commitment. These are affirmed by the following words:

For doctors: 
- "I will be very happy to spend the rest of my life in my career. But not necessarily within this hospital. I' m not interested in walls, I love my career. I cannot change medicine by selling eggs or selling houses; I can change my house but I cannot change my life."

- "I will willingly spend the rest of my professional life in medicine. But not necessarily within this hospital

- "I don' t feel emotionally attached to this hospital. Because the conditions are not favorable."

- "Medicine is the profession I love, I can't change it, it's my life."

- "Our specialty is human. This is why I love my job, I will do the impossible for medicine."

For pharmacists:

- "I have a specialty that is wrong with the position I hold and I think I will change this hospital [...] I will not be happy to spend the rest of my life in this hospital."

- "How will I get a commitment when I feel stressed at work [...] if I find another position that offers favorable conditions I leave my current position."

For administrators:

- "I work without being emotionally attached to this hospital."

- "I don't have a strong sense of belonging to this hospital."

For nurses:

- "The feeling of belonging depends on the number of years working at the hospital, the motivation, recognition and appreciation of the efforts of the staff. Regarding the nurse, there is no valuation. They say he's only a nurse! Even if you ask the nurse why you chose this job, he replies, I chose him at random because I couldn't find another job."

- "I only have a 50\% sense of belonging [...] I think I have to leave this hospital because there is no respect."

\section{Secondary proposition 2: Continuance Commitment}

The degree of calculated commitment also differs depending on the status of the actors. Doctors say they don't have a calculated commitment. They join not because they need to, but because they have an emotional attachment to the medical career. On the other hand, for the other actors, we find that they prove their commitments to their hospital, because they need it. They act like pragmatic people.

The words of the following interviewees are proof of what we are saying:

For doctors:

- "There will be no problem and no consequences for my life if I leave this hospital, it is not the financial side that makes me stay in this hospital [...] For my part, stay with this hospital it's a desire, it's the career that I simply love."

- "I work here, it's because I love medicine, it's the only reason that holds me back with this hospital"

- "I feel like I'm doing the job that I love. I can practice medicine at any hospital in Morocco [...]"

For pharmacists:

- "Staying in this hospital is a necessity, but I prefer to change. It's not because of the money, but because of the stress."

- "It's normal to look for what is best for your career and for your life, so of course, I have to change hospitals if I have a better job offer [...] Currently, I am thinking of changing my job from pharmacist."

For administrators:

- "[...] we try to find what is best for our career."

- "[...] The financial and social side influence our choices [...] I am thinking of leaving this city and going to salé to be close to my house and my children."

For a nurse: "I work in this hospital because I need to work. If I find better, I will change hospitals."

\section{Secondary proposition 3: Normative Commitment}

All the actors evoke that they do not have a normative commitment as it appears in the responses of the following interviewees:

For doctors:

- "I proposed to the administration projects for the improvement of our service. She gave me promises to help me and to grant me all the means to carry out these projects but unfortunately, she did not fulfill her commitments. So how do you expect me to have a commitment? The administration killed my ambitions and my commitment."

- "I really like medicine. In addition to the function of head of department, I do scientific research. But to tell me if I will be faithful to this hospital, my answer will be no ".

- "Staff do not have to be necessarily loyal to their hospital."

- "In general, the staff should not be loyal to their hospital, but as long as I am there, I must give the maximum of myself."

For pharmacists: 
- "To improve oneself, leaving the hospital is not unethical behavior."

- "Staff do not have to be loyal to their hospital."

- "We need favorable conditions, everyone is looking to evolve. We must not miss the opportunities."

For an administrator: "Leaving the hospital is not unethical behavior! "

For a nurse: "Of course, I have to leave the hospital even if I am involved in a project so as not to miss the opportunity; If you have an opportunity, you must not miss it."

\section{ANALYZES OF THE RESULTS}

Theoretical analysis has made it possible to identify three dimensions of commitment: affective commitment, calculated commitment and normative commitment (Allen and Meyer, 1991). Simply put, worker commitment is determined by whether they need it (calculated), want it (emotional), or are obligated (normative).

Empirical analysis shows, according to respondents, the importance of commitment in IFR. When there is commitment, the will to work in a spirit of coordination among the members of the CHU alpha SC will be strong.

We have also noted that the degree of commitment through its three dimensions (affective, calculated and normative) differs according to the status of the actors (administrators, doctors, nurses, pharmacists).

\section{Affective Commitment}

Affective commitment is an individual's emotional attachment to the organization. Individuals stay in the organization out of deep desire and volition. He adopts the ideas and goals of the organization as his own (Meyer \& Allen, 1991). The individual feels like a part of the organization for which he works.

Empirical analysis shows that only physicians have an emotional commitment. Therefore, this type of commitment is oriented towards the profession of medicine and not towards the CHU alpha. They are motivated to work because of their degree of emotional attachment to the medical profession and not to CHU alpha.

Pharmacists, administrators and nurses say they don't have an emotional commitment. They are found to be unattached emotionally and lack motivation towards the hospital.

Therefore, the study shows the absence of organizational emotional commitment. We decide to place the sub-proposal (1) at a low level of acceptance.

\section{Continuance Commitment}

Calculated commitment refers to an individual's knowledge of the costs associated with leaving the organization. Individuals become involved because the costs associated with other behavior are too high, not because they have an emotional attachment to the object of their commitment (Meyer \& Allen, 1984). The individual proves his loyalty to his organization because he needs it. He acts like a pragmatic person who realizes that he will gain more benefits than disadvantages if he stays with the company. So the employee realizes that leaving their organization comes with costs.

Empirical analysis shows that physicians do not have a calculated commitment. These actors are hired not because they need to, but because they have an emotional attachment to the medical career.

In contrast, for other actors, we find that they engage because the costs associated with other behavior are too high, and not because they have an emotional attachment to the object of their commitment. These actors prove their commitment to their hospital, because they need it. They act like pragmatic people. They will get more benefit than harm if they stay in the hospital.

Thus, according to administrators, pharmacists and nurses, calculated commitment positively influences the IFR. On the other hand, according to the doctors, this influence is weak. We decide to place the subproposal (2) at an intermediate level of acceptance.

\section{Normative Commitment}

Normative commitment refers to the feeling of obligation to remain working in the organization out of moral duty, loyalty or to complete a project in which the person is engaged.

Guest (1998) explains the employee's attachment to the organization by the notion of psychological contract, which was defined by Schein (1978) as a number of unspoken reciprocal expectations between employee and organization.

Empirical analysis shows that CS actors do not give importance to normative commitment in coordination. Actors, according to those interviewed, do not have a sense of obligation to continue working in the hospital. The absence of normative attachment is explained by the non-respect of the psychological contract by the hospital administration and therefore implicitly the absence of reciprocity. We decide to place the sub-proposal (3.3) at a low level of acceptance.

In conclusion: Empirical analysis has shown that commitment has a history of IFR. We have identified 
European Journal of Humanities and Social Sciences www.ej-social.org

affective-type commitment (to the profession and not to the hospital) for physicians and calculated-type commitment for other actors. We thus decide to prescribe the commitment of the actors of the HCS in commitment of the calculated type. We place the main proposition (3) at the intermediate acceptance level of acceptance. These results are summarized in the following table:

\begin{tabular}{ccc} 
TABLE VI: THE DEGREE OF ACCEPTANCE OF RESEARCH PROPOSALS \\
\hline \hline \\
$\begin{array}{c}\text { High degree of } \\
\text { acceptance }\end{array}$ & $\begin{array}{c}\text { Intermediate level } \\
\text { of acceptance }\end{array}$ & $\begin{array}{c}\text { Low degree of } \\
\text { acceptance }\end{array}$ \\
\hline Main proposal: Organisational Commitment & $\checkmark$ & $\checkmark$ \\
Secondary proposition 1: Affective Commitment & $\checkmark$ & $\checkmark$ \\
Secondary proposition 2: Continuance Commitment & & $\checkmark$ \\
Secondary proposition 3: Normative Commitment & & $\checkmark$ \\
\hline \hline
\end{tabular}

The set of results leads to a new presentation of the research model according to the research results presented in the following figure.



Fig. 3. The corrected research model

\section{CONCLUSION}

This paper allowed us, after analyzing the literature and the proposals of our research, to produce, thanks to an exploratory qualitative study, the determination of the causal relationship between commitment and IFR. We thus found that our empirical analysis confirmed that (calculated) commitment remains a determinant of IFR in the context of HCS. The actors become involved because the costs associated with other behavior are too high, and not because they have an emotional or normative attachment to the object of their commitment.

\section{REFERENCES}

Acharyulu G. (2012), Leveraging Customer Relationship Management (CRM) in Corporate Hospital Supply Chain. The IUP Journal of Supply Chain Management, vol 1. IX, $\mathrm{n}^{\circ}$

Andre V. \& Fenis P. (2007). Modélisation et simulation des flux logistiques du Nouvel Hôpital d'Etaing. Logistique et Management. Vol.15-N $\mathrm{N}^{\circ}$, 2007. p.49-59.

Ballou, R.L., Gilbert, S.M., \& Mukherjee, A. (2000). New Managerial Challenges from Supply Chain Opportunities. Industrial Marketing Management, 29 (1), 7-18. http://dx.doi.org/10.1016/S0019-8501(99)00107-8

Belin-Munier, (2008). Innovation et Supply Chain Management, Etude du lien entre innovation et mode de coordination des chaines logistiques multi acteurs. http://hal.inria.fr/docs/00/76/24/02/PDF/Belin-Munier.pdf

BELKHOUTOUT, K (2019). Les Fondements de la qualité relationnelle : Une revue de littérature succincte \& liens causaux Revue Internationale des Sciences de Gestion

Berraho, M., Begdouri, A., Elrhazi, K., Elfakir, S., Boumane, A., Talbi, A., et Nejjari, C. (2006). Projet de mise en place d'un Système d'Information Hospitalier au nouveau CHU de Fès (Maroc). Quatrième conférence francophone en gestion GISEH Luxembourg, du 13 au 15 septembre.

Bouachouch \& M. Mamad. (2014). Analysis of the Antecedents of Inter-Functional Coordination in the Supply Chain Context: Case of the Medicament Flows in a Moroccan University Hospital. International Journal of Business and Management; 9(8).

Bouachouch, F.O. (2015) Chahdi. The Effect of Information Exchange on Inter-Functional Coordination within Hospital Supply Chain: Case of Moroccan University Hospital . International Journal of Academic Research in Business and Social Sciences, $5(1)$.

Bourlakis, M. Clear F. et Patten, L. (2011). Understanding the UK hospital supply chain in an era of patient choice, Journal of Marketing Management, 27(3-4). 
Buchanan, (1974). Building Organizational Commitment: The Socialization of Managers in Work Organizations. in Administrative Science Quarterly 19(4) • December 1974 with 3,884 Reads DOI: 10.2307/2391809

Costin, M., \& Chitou, I., (2012). Démarche logistique - une performance organisationnelle pour une meilleure satisfaction des patients. Cas du Groupe des Hôpitaux Universitaires Paris-Ouest. 9es RIRL.2012. 15-17 Aout HEC Montreal Canada.

DI Martinelly, C., Guinet, A., \& Riane, F. (2005). Chaîne logistique en milieu hospitalier : modélisation des processus de distribution de la pharmacie. 6e Congrès international de génie industriel - 7-10 juin 2005-Besançon.

Eng, T.Y. (2005). An investigation into the mediating role of cross-functional coordination on the linkage between organizational norms and SCM performance. Industrial Marketing Management 35 (2006) 762 - 773.

Feng, W. (2010). Le Supply Chain Management et la culture : la mise en oeuvre du Supply Shain Management dans le contexte culturel chinois. Université de la méditerranée- Aix Marseille II.

Guest, D. E. (1998). Is the psychological contract worth taking seriously? Journal of Organizational Behavior, vol. 19.

Hennig-Thurau, T., \& Klee, A. (1997). The impact of customer satisfaction and relationship quality on customer retention: A critical reassessment and model development. Psychology and Marketing 14(8), 737-764

Ibn El Farouk I., Talbi A. et Jawab F (2012), Chaîne logistique hospitalière : définition, état de l'art et pistes d'amélioration, CIGIMS 2012, FES/ MAROC.

Kanter, R. M. (1968), Commitment and Social Organization: A Stady of Commitment Mechanisms in Utopian Communities, American Sociological Review, 33.

Kosremelli, A. M. (2011). La collaboration interprofessionnelle : cas d'un service de pédiatrie d'un hôpital universitaire au Liban. Thèse de doctorat en Sciences de Gestion, Université de Dauphne de Paris.

Kotter, J. P. (1973). The Psychological Contract: managing the Joining-up Process, California Management Review (pre-1986). Berkeley, 5(3).

McKee, M., et Healy, J. (2000), Le rôle de l'hôpital dans un environnement en mutation, Bulletin de l'Organisation Mondiale de la Santé, 3 .

Mentzer J.T., Dewitt W., Keeber J.S., Min S., Nix N.W., Smith C.D, \& Zacharia Z.G., (2001). Defining the Supply Chain Management. Journal of Business Logistics, 2(2). http://dx.doi.org/10.1002/j.2158-1592.2001.tb00001.x.

Mentzer, J.T. (1993). Managing Channel Relations in the 21st Century. Journal of Business Logistics, 14(1), 27-42.

Meyer, J. P. \& Allen, N. J. (1991). A Three-Component Conceptualization of organizational commitment. Human Resource Management Review, 1(1), 61-89. http://dx.doi.org/10.1016/1053-4822(91)90011-Z

Min, S. 2001. Interfunctional coordination. In J. Mentzer, Supply Chain Management Thousand Oaks, CA: SAGE Publications.

Narver, J. C., \& Slater, S. F. (1990). The effect of a market orientation on business profitability. Journal of Marketing, 54(4), 20-35. https://doi.org/10.2307/1251757

Pinto, M.B., Pinto J.K. \& Prescott J.E. (1993). Antecedents and Consequences of Project Team Cross-functional Cooperation. Management Science, 39(10). http://dx.doi.org/10.1287/mnsc.39.10.1281.

Schein, E.H. (1985). How culture forms, develops and changes. in: Kilmann, R.H. and associates, Gaining control of the corporate culture, Jossey Bass, San Francisco.

Sheldon, (1971). Investments and Involvements as Mechanisms Producing Commitment to the Organization. Administrative Science Quarterly, 16(2), 143-150.

Taher, H. (2006). Logistique hospitalière: organisation de la chaîne logistique pharmaceutique aval et optimisation des flux de consommables et des matériels à usage unique. Thèse de doctorat en science de gestion, l'Université (Claude Bernard - Lyon 1)

Thiétart, R.A. (2007). Méthodes de recherche en management. 3ème édition, Paris: Dunod.

Zakari M., Poku K. \& Owusu-Ansah W. (2013). Organizational Culture and Organisational Performance: Empirical Evidence from the Banking Industry. International Journal of Business, Humanities and Technology, 3(1). 